\title{
Aplikasi Android Contruct 2 untuk Media E-Learning pada Materi Peluang
}

\author{
Fachri Ridho $^{1}$, Bambang Sri Anggoro ${ }^{1}$, Siska Andriani ${ }^{1}$ \\ ${ }^{1}$ Universitas Islam Negeri Raden Intan Lampung. Jalan Endro Suratmin, Sukarame, Bandar \\ Lampung 35133, Indonesia. \\ * Corresponding Author. E-mail: fachriridho3@gmail.com
}

\begin{abstract}
Abstrak
Penelitian ini bertujuan untuk menghasilkan media pembelajaran E-Learning berbasis aplikasi android construct 2 pada materi peluang. Metode penelitian ini adalah Research and Development (R\&D) berdasarkan model pengembangan Sugiyono. Penilaian ahli materi terhadap media pembelajaran ini termasuk dalam kategori "Baik" dengan persentase rata-rata sebesar 79.05\%. Penilaian ahli media terhadap media pembelajaran ini termasuk dalam kategori "Sangat Baik" dengan persentase rata-rata sebesar $87.67 \%$, penilaian praktisi pendidikan terhadap media pembelajaran ini termasuk dalam kategori "Sangat Baik" dengan persentase ketuntasan sebesar 82.57\%. Pada uji coba skala kecil yang diikuti oleh 10 peserta didik kelas XI memperoleh persentase sebesar $81,60 \%$. Berdasarkan hasil dari angket respon yang telah diisi oleh peserta didik, hasil ini menempatkan bahwa media pembelajaran pada kriteria "Sangat Menarik". Berdasarkan hasil uji coba skala besar yang diikuti oleh 30 peserta didik kelas XI memperoleh persentase sebesar 88,78\% termasuk dalam kriteria "Sangat Menarik", dan hasil uji coba keefektifan media pembelajaran memperoleh persentase sebesar $88,33 \%$ termasuk dalam kriteria "Sangat Efektif".
\end{abstract}

Kata kunci: Media Pembelajaran E-Learning, Construct 2

\section{Abstract}

This study aims to produce an Android-based E-Learning learning media on opportunity material. This research method is Research and Development ( $R \& D)$ based on Sugiyono's development model. The material expert's assessment of the learning media is included in the "Good" category with an average percentage of 79.05\%. The media expert's assessment of the learning media is included in the "Very Good" category with an average percentage of 87.67\%, the assessment of education practitioners on this learning media is included in the "Very Good" category with a percentage of completeness of $82.57 \%$. In a small scale trial which was attended by 10 students in class XI obtained a percentage of $81.60 \%$. Based on the results of the questionnaire responses that have been filled in by students, these results place the learning media on the criteria of "Very Interesting". Based on the results of a large-scale trial which was attended by 30 students of class XI, the percentage of $88.78 \%$ was included in the criteria of "Very Interesting", and the results of the testing of the effectiveness of learning media were $88.33 \%$ included in the criteria of "Very Effective".

Keywords: Instructional Learning, Construct 2

\section{PENDAHULUAN}

Teori peluang merupakan cabang matematika yang berhubungan dengan analisis acak. Sebagai dasar matematika khususnya statistika, teori peluang sangat penting dalam beberapa aktivitas manusia yang melibatkan analisis kuantitatif serangkaian data. Banyak peneliti dalam sains dan perindustrian menggunakan perhitungan probabilitas berdasarkan hasil di masa lalu untuk memprediksikan dan merencanakan masa depan.

Kaidah pencacahan yang dapat digunakan mencakup salah satu atau beberapa metode, antara lain aturan pengisian tempat yang tersedia, permutasi dan kombinasi.

Pendidikan merupakan salah satu bidang yang terus berkembang seiring 
dengan perkembangan ilmu pengetahuan dan teknologi, oleh karena itu pembaharuan pada bidang pendidikan sangat penting untuk dilakukan. Bila masyarakat mengalami kemajuan dalam bidang ilmu pengetahuan, maka di dalamnya banyak individu yang mendapat kemudahan hidup, kesejahteraan, dan kemudahan untuk mengekspresikan kemanusiaannya baik dalam kehidupan individu maupun kelompok (Yahdi, 2016).

Perkembangan IPTEK membawa implikasi pada tiap generasi dalam berbagai bidang ilmu pengetahuan. Saat ini konsep e-Learning sudah banyak diterima oleh masyarakat dunia, terbukti dengan maraknya implementasi $e$ Learning di lembaga pendidikan (sekolah, training dan universitas). Pemanfaatan jaringan komputer atau handphone berupa internet sebagai media pembelajaran mengondisikan peserta didik untuk belajar secara mandiri. Jadi peserta didik dapat berperan sebagai seorang peneliti, menjadi seorang analis, tidak hanya konsumen informasi saja. Peserta didik dan pendidik tidak perlu hadir secara fisik dikelas (classroom meeting), karena peserta didik dapat mempelajari materi dan mengerjakan tugas-tugas pembelajaran serta ujian dengan cara mengakses jaringan komputer yang telah ditetapkan secara online. Penerapan internet yang paling jelas implementasinya sekarang ini adalah penggunaan e-learning untuk penyebaran informasi dan berkomunikasi.

Pengertian E-Learning di dunia pendidikan dan pelatihan sekarang, banyak sekali praktik yang disebut ELearning. Sampai saat ini pemakaian kata E-Learning sering digunakan untuk menyatakan semua kegiatan pendidikan yang menggunakan media komputer dan Internet (Nuryadi, 2018). Istilah "e" atau singkatan dari elektronik dalam elearning digunakan sebagai istilah untuk segala teknologi yang digunakan untuk mendukung usaha-usaha pengajaran lewat teknologi elektronik internet (Yazdi, 2012).

Hasil wawancara yang dilakukan oleh peneliti kepada salah satu guru matematika di SMA Persada Bandar Lampung mengatakan bahwa, pembelajaran matematika menjadi menarik dengan cara mengaplikasikannya ke kehidupan nyata. Selain itu juga beliau mengatakan sumber belajar yang masih menggunakan buku paket dan LKS, peserta didik pun masih kesulitan untuk memahami materi karena sarana yang belum memadai dan menginginkan inovasi baru berupa aplikasi android pada proses pembelajaran.

Menciptakan proses pembelajaran yang menarik dan menyenangkan yaitu dapat memanfaatkan ilmu teknologi, seperti yang dijadikan sebagai media pembelajaran untuk menunjang proses pembelajaran berlangsung. Tidak hanya teknologi informasi dan komunikasi bisa diwujudkan dalam bidang pendidikan tetapi sesuatu yang sudah melekat pada bangsa Indonesia yaitu construct 2 . Construct 2 di Indonesia sangatlah digemari oleh remaja masa kini terutama construct 2 Aplikasi android.

Construct 2 adalah tools yang digunakan dalam membuat sebuah game tanpa memerlukan pengetahuan tentang pemrograman (Oktavia, Sofia, Tyas, Khasnah, \& Marfu'ani, 2015). Sholihin dan Farouq dalam (Saputro, Kriswandani, \& Ratu, 2018) menyatakan bahwa Construct 2 adalah software yang canggih fitur HTML5 Game Creator dirancang.

Berdasarkan hasil penelitian terdahulu, telah dilakukan penelitian untuk mendesain aplikasi pembelajaran berbasis e-learning (Henderi, Maimunah, \& Andrian, 2011; Hernawati \& Aji, 2016; Kristanto, Hapsari, Nita, \& Maimunah, 2015; Kuryanti, 2016; Nuryadi, 2018; Susanti \& Sholeh, n.d.; Utomo, Wahyuningrum, Saptadi, \& Januarita, 2011; Yazdi, 2012). Perbedaan dengan 
produk yang dikembangkan peneliti yaitu peneliti mendesain bahan ajar aplikasi android dengan menggunakan aplikasi construct 2.

Penelitian selanjutnya, peneliti membuat game edukasi berbantuan aplikasi android contruct 2 (Adiwijaya, S, \& Christyono, 2015; Apriyanto \& Lasodi, 2016; Firdaus \& Nugroho, 1945; Oktavia et al., 2015; Putriani, Waryanto, \& Hernawati, 2017; Saputro et al., 2018). Perbedaan dengan produk yang dikembangkan peneliti yaitu peneliti mendesain bahan ajar aplikasi android pada materi peluang.

Berdasarkan beberapa penelitian terdahulu, peneliti memberikan alternatif untuk mengembangkan media pembelajaran berupa bahan ajar matematika pada materi peluang yang menerapkan prinsip-prinsip desain pembelajaraan yang di sajikan dalam bentuk construct 2 aplikasi android yang mengarahkan peneliti untuk mendesain pembelajaran yang digunakan sebagai pedoman dalam penyelenggaraan pembelajaran agar tercapai pembelajaran yang efektif, efisien, berdaya guna yang menarik dan humanis.

\section{METODE}

Metode penelitian ini adalah Research and Development (R\&D) berdasarkan model pengembangan Borg and Gall yang dimodifikasi oleh Sugiyono (Sugiyono, 2011) yang meliputi potensi dan masalah, pengumpulan data, desain produk, validasi desain, revisi desain, uji coba produk, revisi produk, uji coba pemakaian, revisi produk, produk masal, secara umum model penelitian ini dapat dilihat pada Gambar 1.

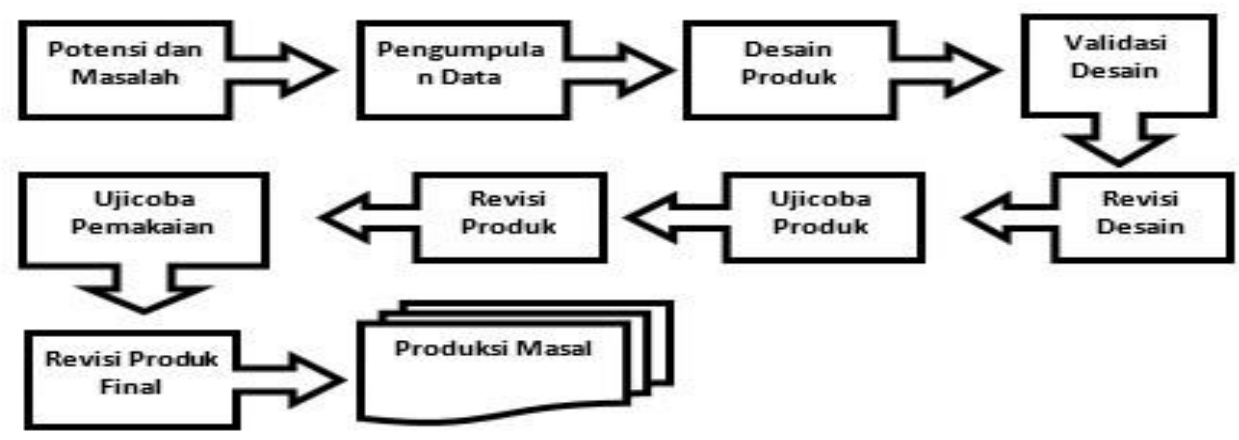

Gambar 1. Langkah-langkah penggunaan metode Research and Development (R\&D)

Pengembangan produk yang dilaksanakan pada penelitian ini hanya sampai pada tahap menghasilkan produk akhir, yaitu bahan ajar aplikasi android dengan menggunakan aplikasi construct 2 . Peneliti tidak membatasi menjadi tujuh langkah dari sepuluh langkah karena aplikasi android construct 2 dapat di unggah melalui play store yaitu diantaranya: potensi dan masalah, mengumpulkan informasi, desain produk, validasi desain, perbaikan desain, uji coba produk, revisi produk,uji coba pemakaian, revisi produk, produksi masal.
Teknik pengumpulan data dalam penelitian pengembangan aplikasi android ini menggunakan tiga jenis, yaitu wawancara, dokumentasi dan kuesioner (angket). Instrumen adalah alat yang berfungsi untuk mempermudah pelaksanaan sesuatu. Berdasarkan pada tujuan penelitian, dirancang dan disusun instrumen sebagai berikut: 1) Instrumen studi pendahuluan, 2) Instrumen validasi oleh ahli materi, ahli bahasa, dan praktisi pendidikan dan 3) Instrumen uji coba produk.

Teknik analisis data dalam penelitian ini dilakukan dengan 
menggunakan langkah-langkah sebagai berikut:

1. Teknik Analisis Data Kualitatif

Data kualitatif berupa kritik dan saran produk aplikasi android matematika berbantuan game offline sebagai alternatif pembelajaran yaitu penilaian oleh ahli materi, ahli media dan pendidik SMA Persada Bandar Lampug.

2. Teknik Analisis Data Kuantitatif

Kualitas media pembelajaran matematika yang diperoleh dari pengisian lembar penilaian oleh para ahli dan respon peserta didik dimuat dalam bentuk table kelayakan produk. Kemudian data dijadikan landasan untuk melakukan revisi setiap komponen dari media pembelajaran matematika yang telah disusun, selanjutnya di analisis untuk mengetahui kualitas media pembelajaran. Berikut langkah-langkah dalam menganalisis data instrumen validasi ahli media, materi dan respon peserta didik:

Berikut langkah-langkah dalam menganalisis data instrumen validasi ahli media dan materi :

a) Langkah pertama adalah memberikan skor pada tiap kriteria dapat dilihat pada Tabel 1.

Tabel 1. Pedoman Skor Penilaian Ahli Media dan Materi

\begin{tabular}{lr}
\hline \multicolumn{1}{c}{ Kriteria } & Skor \\
Sangat Baik (SB) & 5 \\
Baik (B) & 4 \\
Cukup (C) & 3 \\
Kurang (K) & 2 \\
Sangat Kurang (SK) & 1 \\
\hline
\end{tabular}

b) Selanjutnya dilakukan perhitungan tiap butir pernyataan menggunakan rumus sebagai berikut:

$P=\frac{\text { jumlah skor hasil pengumpulan data }}{\text { jumlah skor kriterium }} \times 100 \%$

Keterangan:

$\mathrm{P}=$ persentase kelayakan.

c) Langkah terakhir adalah menyimpulkan hasil perhitungan berdasarkan aspek dapat dilihat pada Tabel 2 .

Tabel 2. Range Persentase dan Kriteria Kualiatif Program

\begin{tabular}{cl}
\hline Skor Persentase (\%) & Interpretasi \\
$80<\mathrm{P} \leq 100$ & Sangat Baik \\
$60<\mathrm{P} \leq 80$ & Baik \\
$40<\mathrm{P} \leq 60$ & Cukup Baik \\
$20<\mathrm{P} \leq 40$ & Kurang Baik \\
$0 \leq \mathrm{P} \leq 20$ & Sangat Tidak \\
& Baik \\
\hline
\end{tabular}

d) Data hasil posttest digunakan untuk menentukan analisis keefektifan pembelajaran menggunakan media pembelajaran yang dibuat. Keefektifan dilakukan menggunakan menganalisis test hasil belajar pada posttest. Nilai maksimal untuk test ini adalah 100. Kriteria ketuntasan menggunakan Kriteria Ketuntasan Minimal (KKM) sesuai dengan tempat penelitian di SMA Persada Bandar Lampung yaitu 75. Analisis dilakukan secara sederhana dengan tahapan sebagai berikut:

a. Tabulasi data test hasil belajar.

b. Mengubah data test hasil belajar dengan tabel keefektifan pembelajaran (Soewand \& Selamat, 2015).

Tabel 3. Pedoman Keefektifan Pembelajaran

\begin{tabular}{cl}
\hline Skor Persentase (\%) & Interpretasi \\
$80<\mathrm{P} \leq 100$ & Sangat Baik \\
$60<\mathrm{P} \leq 80$ & Baik \\
$40<\mathrm{P} \leq 60$ & Cukup Baik \\
$20<\mathrm{P} \leq 40$ & Kurang Baik \\
$0 \leq \mathrm{P} \leq 20$ & Sangat Tidak \\
& Baik \\
\hline
\end{tabular}

$\mathrm{P}=\frac{P a}{P b} \times 100 \%$

Keterangan:

$\mathrm{P}=$ Persentase ketuntasan siswa

$\mathrm{P}_{\mathrm{a}}=$ Jumlah siswa tuntas

$\mathrm{P}_{\mathrm{b}}=$ Jumlah siswa keseluruhan 


\section{HASIL DAN PEMBAHASAN}

Penelitian ini dilakukan untuk mengembangkan media pembelajaran matematika menggunakan aplikasi android contruct 2, hasil validasi pada media pembelajaran ini melalui validasi dengan ahli materi, ahli media, praktisi pendidikan dan peserta didik yang dibagi menjadi ujicoba kelas kecil dan ujicoba kelas besar. Media pembelajaran matematika yang dihasilkan berupa elearning yaitu game android yang diberi nama MaDu (Matematika Edukasi) menggunakan aplikasi construct 2 yang didalamnya memuat materi peluang untuk siswa kelas X SMA. Media pembelajaran ini dikembangkan menggunakan metode pengembangan Sugiyono. Adapun langkah-langkah pengembangan produk sebagai berikut: potensi dan masalah, mengumpulkan informasi, desain produk, validasi desain, perbaikan desain, uji coba produk, revisi produk, uji coba pemakaian, revisi produk, dan produksi masal. Penilaian materi dilakukan oleh dua orang ahli yaitu dosen matematika UIN Raden Intan Lampung. Penilaian mediaPenilaian validator terhadap media pembelajaran yang dikembangkan dapat dilihat pada Tabel 4.

Tabel 4. Persentase Penilaian Validator dan Kriteria Kualitatif Program

\begin{tabular}{lccc}
\hline \multicolumn{1}{c}{ Validator } & Ahli Materi & Ahli Media & Praktisi Pendidikan \\
$\begin{array}{l}\text { Persentase Rata-rata } \\
\text { Kriteria }\end{array}$ & Baik & $87,67 \%$ & $82,57 \%$ \\
& Sangat Baik & Sangat Baik \\
\hline
\end{tabular}

Berdasarkan Tabel 4 dapat dilihat penilaian dari ahli materi terhadap media pembelajaran memperoleh persentase rata-rata sebesar 79,07\% dengan kriteria "Baik". Penilaian dari ahli media terhadap media pembelajaran memperoleh persentase rata-rata sebesar 87,67\% dengan kriteria "Sangat Baik". Penilaian dari praktisi pendidikan memperoleh persentase rata-rata sebesar 82,57\% dengan kriteria "Sangat Baik". Oleh sebab itu, media pembelajaran berupa game android yang dikembangkan layak digunakan dalam kelas pembelajaran. Hasil uji coba kelas kecil dan kelas besar dapat dilihat pada Tabel 5 .

Tabel 5. Hasil Uji Coba dan Kriteria Kualitatif Program

\begin{tabular}{lcc}
\multicolumn{1}{c}{ Hasil Uji Coba } & $\begin{array}{c}\text { Kelas } \\
\text { Kecil }\end{array}$ & $\begin{array}{r}\text { Kelas } \\
\text { Besar }\end{array}$ \\
$\begin{array}{l}\text { Persentase rata- } \\
\text { rata } \\
\text { Kriteria }\end{array}$ & $88,78 \%$ & $88,78 \%$ \\
& $\begin{array}{l}\text { Sangat } \\
\text { Menarik }\end{array}$ & $\begin{array}{l}\text { Sangat } \\
\text { Efektif }\end{array}$ \\
\hline
\end{tabular}

Berdasarkan Tabel 5 diatas dapat dilihat bahwa hasil uji coba kelas kecil memperoleh persentase rata-rata sebesar
88,78\% dengan kriteria "Sangat Menarik" dan hasil uji coba kelas besar memperoleh persentase rata-rata sebesar $88,78 \%$ dengan kriteria "Sangat Efektif".

\section{SIMPULAN DAN SARAN}

Berdasarkan uraian pada hasil dan pembahasan diatas maka dapat disimpulkan bahwa 1) Media pembelajaran matematika yang dihasilkan berupa e-learning yaitu game android yang diberi nama MaDu (Matematika Edukasi) menggunakan aplikasi construct 2 yang didalamnya memuat materi peluang untuk siswa kelas X SMA. Media pembelajaran ini dikembangkan menggunakan metode pengembangan Sugiyono. Adapun langkah-langkah pengembangan produk sebagai berikut: potensi dan masalah, mengumpulkan informasi, desain produk, validasi desain, perbaikan desain, uji coba produk, revisi produk, uji coba pemakaian, revisi produk, dan produksi masal. 2) Respon peserta didik terhadap media pembelajaran yang dikembangkan sangat baik. Hal itu dapat dilihat dari hasil uji coba skala kecil memperoleh persentase sebesar $81,60 \%$ 
dikategorikan sangat baik, hasil uji coba skala besar memperoleh persentase sebesar $88,78 \%$ dikategorikan sangat baik, dan hasil uji coba keefektifan memperoleh persentase sebesar 83,33\% dikategorikan sangat efektif. Sehingga dapat disimpulkan bahwa media pembelajaran yang dikembangan sangat baik untuk digunakan dalam kelas pembelajaran di kelas $\mathrm{X}$ pada materi peluang.

Berdasarkan hasil penelitian yang dilakukan peneliti, maka peneliti memberikan saran untuk penelitian selanjutnya yaitu media pembelajaran matematika yang dihasilkan berupa elearning yaitu game android yang diberi nama $\mathrm{MaDu}$ (Matematika Edukasi) menggunakan aplikasi construct 2 bisa dikembangkan lagi pada mata pelajaran selain matematika dan materi yang lebih luas lagi.

\section{DAFTAR PUSTAKA}

Adiwijaya, M., S, K. I., \& Christyono, Y. (2015). Perancangan Game Edukasi Platform Belajar Matematika Berbasis Android Menggunakan Construct 2. Transient, 4(1), 128133.

Apriyanto, A., \& Lasodi, I. S. (2016). Pembuatan Game Labirin Menggunakan Aplikasi Construct 2 Berbasis Online. Jesik: Jurnal Elektronik Sistem Informasi Dan Komputer, 2(2).

Firdaus, M., \& Nugroho, H. W. (1945). Rancang Bangun Game Edukasi Asah Otak Anak Berbasis Android Menggunakan Aplikasi Construct 2, 1-10.

Henderi, Maimunah, \& Andrian, R. (2011). Desain Aplikasi E-Learning sebagai Media, 4(3), 316-330.

Hernawati, E., \& Aji, P. (2016). Perancangan dan Penerapan Konten E-Learning Melalui Learning Management System dalam Meningkatkan Motivasi Belajar.
Journal of Information Systems Engineering and Business Intelligence, 2(1), 23-32.

Kristanto, T., Hapsari, R. K., Nita, V. S., \& Maimunah, S. (2015). Rancang Bangun Aplikasi E-Learning Berbasis Multiplatform untuk Mata Pelajaran Bahasa Indonesia dengan Menggunakan Pendekatan Technology Acceptance Model (TAM). Jurnal Teknik Informatika dan Sistem Informasi, 1(3), 279-290.

Kuryanti, S. J. (2016). Rancang Bangun Sistem E-Learning sebagai Sarana Pembelajaran. Jurnal Khatulistiwa Informatika, 4(1), 84-92.

Nuryadi, N. (2018). Rancang Bangun Aplikasi Website E-Learning pada SMK Respati 1 Jakarta. Jurnal Teknik Komputer, 4(1), 162-167.

Oktavia, N., Sofia, A., Tyas, L., Khasnah, N. I., \& Marfu'ani, N. R. (2015). Pembuatan Game Edukasi Berbasis Construct 2 sebagai Media Pembelajaran Fisika untuk Siswa Sekolah Menengah Pertama. Proseding Seminar Nasional Fisika dan Aplikasinya, 56-67.

Putriani, D., Waryanto, N. H., \& Hernawati, K. (2017). Pengembangan Media Pembelajaran Berbasis Android dengan Program Construct 2 pada Materi Bangun Ruang Sisi Datar untuk Siswa SMP Kelas 8. Jurnal Pendidikan Matematika, 6(3), 1-10.

Saputro, T. A., Kriswandani, \& Ratu, N. (2018). Pengembangan Media Pembelajaran Mengunakan Aplikasi Construct 2 pada Materi Aljabar Kelas VII. JTAM: Jurnal Teori dan Aplikasi Matematika, 2(1), 1-8.

Soewand, \& Selamat. (2015). Perspektif Pembelajaran di Berbagai Bidang. Yogyakarta: USD.

Sugiyono. (2011). Metode Penelitian Kuantitatif Kualitatif dan R\&D. Bandung: Alfabeta.

Susanti, E., \& Sholeh, M. (N.D.). Rancang Bangun Aplikasi E-Learning. Jurnal 
Desimal, 2 (2), 2019 - 171

Fachri Ridho, Bambang Sri Anggoro, Siska Andriani

Teknologi, 53-57.

Utomo, E. P., Wahyuningrum, T., Saptadi, A. H., \& Januarita, D. (2011). Rancang Bangun E-Learning Mata Pelajaran Teknologi Informasi dan Komunikasi (TIK) Berbasis Web di SMPN 3 Mandiraja. Jurnal Infotel,
3(1), 1-6.

Yahdi, M. (2016). Paradigma Pendidikan Islam, $V(1), 52-64$.

Yazdi, M. (2012). E-Learning Sebagai Media Pembelajaran Interaktif Berbasis Teknologi Informasi. Jurnal Ilmiah Foristek, 2(1), 143-152. 